Jurnal Health Sains: p-ISSN: 2723-4339 e-ISSN: 2548-1398

Vol. 2, No. 5, Mei 2021

\title{
TINGKAT PENGETAHUAN ANTARA MAHASISWA KESEHATAN DAN NON KESEHATAN TERHADAP PENGGUNAAN VITAMIN C DI UNIVERSITAS TADULAKO SULAWESI TENGAH
}

\author{
Siti Mutmaina Ayu Lestari, Amelia Rumi dan Khusnul Diana \\ Universitas Tadulako Sulawesi Tengah, Indonesia \\ Email: ayhunaim@gmail.com, amelia.rumi@gmail.com dankhusnul_diana@yahoo.com
}

\begin{tabular}{l}
\hline ARTIKEL INFO \\
\hline Tanggal diterima: 5 Mei 2021 \\
Tanggal revisi: 15 Mei 2021 \\
Tanggal yang disetujui: 25 Mei \\
2021 \\
\hline
\end{tabular}

Keywords:

vitamin C; knowledge; use; students; medical; non medical

\section{ABSTRACT}

During the Covid-19 pandemic, it is recommended to use vitamin $C$ in maintaining immunity, especially in students who have high activity. Widespread use can lead to dose abuse, resulting in side effects such as diarrhea, vomiting nausea to the formation of kidney stones. The purpose of this study was to determine the knowledge and use of vitamin $C$ as well as the relationship between both medical and nonmedical students of Tadulako University. This study used cross sectional method by collecting data through questionnaires in Google Form in 747 medical and nonmedical students in the class of 2017-2019. Sampling techniques using purposive sampling. The results of the study obtained the knowledge of tadulako university medical students about vitamin $C$ entered the sufficient category (47.01\%) and non-medical students were included in the low category (59.01\%). For the use of vitamin C, medical students fall into the high category (61.54\%) and nonmedical students were included in the sufficient category (48.74\%). The results of the chi-square test, there is a significant relationship between knowledge and the use of vitamin $C$, with $p$ value 0.000 ( $p$ value <0.05). The conclusion from the research, the knowledge of medical students about vitamin $C$ and its use is better than nonmedical students, and there is a link between the knowledge and use of vitamin $C$ in tadulako university students.

\begin{abstract}
ABSTRAK
Pada masa pandemi Covid-19 lebih disarankan penggunaan vitamin $\mathrm{C}$ dalam menjaga imunitas tubuh, terutama pada mahasiswa yang memiliki aktivitas tinggi. Maraknya penyalahgunaan dosis yang berlebihan dapat menimbulkan efek samping berupa diare, mual muntah hingga pembentukan batu ginjal. Tujuan dari penelitian ini untuk mengetahui pengetahuan dan penggunaan vitamin $\mathrm{C}$ serta hubungan keduanya pada mahasiswa kesehatan dan non kesehatan Universitas Tadulako. Penelitian ini menggunakan metode cross sectional dengan pengambilan data melalui kuesioner di Google Form pada 747 mahasiswa kesehatan dan non kesehatan angkatan 2017-2019. Teknik pengambilan
\end{abstract}

$\begin{array}{ll}\text { How to cite: } & \text { Lestari, Siti Mutmaina Ayu, et. al (2021) Tingkat Pengetahuan antara Mahasiswa Kesehatan dan } \\ & \text { Non Kesehatan terhadap Penggunaan Vitamin C di Universitas Tadulako Sulawesi Tengah. Jurnal } \\ & \text { Health Sains 2(5). https://doi.org/10.46799/jhs.v2i5.165 } \\ \text { E-ISSN: } & \text { 2723-6927 } \\ \text { Published by: } & \text { Ridwan Institute }\end{array}$


sampel menggunakan purposive sampling. Hasil penelitian, pengetahuan mahasiswa kesehatan Universitas Tadulako tentang vitamin C masuk kategori cukup $(47,01 \%)$ dan mahasiswa non kesehatan masuk kategori kurang $(59,01 \%)$. Untuk penggunaan vitamin $\mathrm{C}$, mahasiswa kesehatan masuk kategori baik $(61,54 \%)$ dan mahasiswa non kesehatan masuk kategori cukup $(48,74 \%)$. Hasil uji chi-square, terdapat hubungan signifikansi antara pengetahuan dengan penggunaan vitamin $C$, dengan $p$ value 0,000 ( $p$ value $<0,05$ ). Kesimpulan penelitian ini, pengetahuan mahasiswa kesehatan

Kata Kunci:

vitamin C; pengetahuan; penggunaan; mahasiswa; kesehatan; non kesehat tentang vitamin $\mathrm{C}$ dan penggunaannya lebih baik dari mahasiswa non kesehatan, serta terdapat hubungan antara pengetahuan dan penggunaan vitamin $\mathrm{C}$ pada mahasiswa Universitas Tadulako.

\section{Pendahuluan}

Salah satu vitamin yang dipercaya dapat membantu proses metabolisme tubuh pada remaja adalah vitamin C. Vitamin C merupakan vitamin larut air yang bersifat esensial serta banyak digunakan sebagai suplemen untuk tubuh. Vitamin ini dapat diperoleh melalui asupan sayur-sayuran, buahbuahan serta suplemen vitamin C (Siti et al., 2016). Vitamin ini memiliki sifat tidak stabil yang akan mudah rusak jika terkena paparan udara dan panas yang berlebih (Ngginak et al., 2019).

Secara umum fungsi vitamin C adalah sebagai antioksidan. Selain itu, vitamin C sendiri mampu merangsang kekebalan tubuh dengan terjadinya peningkatan proliferasi sel $\mathrm{T}$ dalam merespon infeksi. Beberapa fungsi vitamin $\mathrm{C}$ yang lainnya yaitu pencegahan sariawan, penghambatan nitrosamine (diduga merupakan karsinogen) serta dibutuhkan dalam proses pertumbuhan dan perkembangan (perawatan tulang, gigi dan kolagen) (Wijayanti \& Sungkono, 2017).

Di masa pandemi COVID-19 kebutuhan akan vitamin $\mathrm{C}$ sangat diperlukan untuk memperkuat kekebalan tubuh atau imunitas tubuh sehingga dapat membantu mencegah penularan dari COVID-19 (Polak et al., 2021) Hal inilah yang mendorong seseorang khususnya mahasiswa, harus mengkonsumsi vitamin $\mathrm{C}$ yang dipercaya dapat membantu proses pengaturan atau kegiatan tubuh.

Penelitian yang telah dilakukan oleh (Rhama et al., 2020), bahwa di Kota Palu vitamin $\mathrm{C}$ mengalami peningkatan konsumsi baik sediaan tunggal maupun kombinasi. Peningkatan penggunaan ini terjadi sejak bulan Januari hingga Mei 2020 dengan peningkatan tertinggi pada bulan Maret 2020. Hal ini menunjukan bahwa vitamin $C$ menjadi suplemen dengan penggunaan tertinggi dibandingkan suplemen lainnya pada masa pandemi COVID-19 di Kota Palu.

Maraknya penggunaan vitamin $\mathrm{C}$ pada masa pandemi COVID-19 dapat menyebabkan penyalahgunaan dosis, sehingga akan menimbulkan efek samping yang tidak diinginkan (Sukmawati et al., 2021). Beberapa efek samping yang dapat ditimbulkan antara lain, beresiko terjadinya diare dan mual-muntah, terbentuknya batu ginjal, meningkatkan risiko diabetes, menghambat proses penyembuhan penyakit kanker serta dapat memicu timbulnya alergi, ruam dan iritasi pada kulit (RI, 2016).

Berdasarkan penelitian yang telah dilakukan oleh (Rahmadhani et al., 2017) mengenai tingkat pengetahuan terhadap peran vitamin C pada mahasiswa kedokteran di Universitas Hasanudin Makassar, didapatkan hasil sebanyak $79,66 \%$ mahasiswa memiliki 
tingkat pengetahuan yang cukup. Penelitian yang sama juga dilakukan oleh (Koutsakos et al., 2021) di Universitas Sumatera Utara, dengan hasil sebanyak $86,3 \%$ mahasiswa memiliki pengetahuan yang cukup mengenai peran vitamin $\mathrm{C}$ bagi kesehatan kulit. Kategori pengetahuan mahasiswa yang relatif cukup mengenai pengetahuan dan penggunaan vitamin $\mathrm{C}$ ini dapat mempengaruhi penggunaannya dimana dapat terjadi kelebihan dan kekurangan dari asupan vitamin $\mathrm{C}$ yang diperlukan oleh tubuh.

Pengetahuan dan pemahaman tentang penggunaan vitamin $\mathrm{C}$ tentu berbeda pada setiap orang. Menurut (Trisnawati et al., 2016), mahasiswa merupakan salah satu komponen masyarakat yang memiliki peran penting dalam proses mencerdaskan generasi penerus yang lebih baik serta untuk mengedukasi masyarakat. Menurut (Notoatmodjo, 2012), tingkat pengetahuan seseorang dapat dipengaruhi oleh beberapa faktor yaitu tingkat atau jenis pendidikan yang ditempuh, informasi yang diperoleh oleh seseorang, pengalaman seseorang, budaya serta sosial ekonomi seseorang. Oleh karena itu, peneliti tertarik untuk meneliti pengetahuan mengenai penggunaan vitamin $\mathrm{C}$ yang sedang menjadi trend di masyarakat, pada mahasiswa kesehatan dan non kesehatan dilihat dari perbedaan jenis pendidikannya. Hal inilah yang melatarbelakangi dilakukannya penelitian tingkat pengetahuan antara mahasiswa kesehatan dan non kesehatan terhadap penggunaan vitamin $\mathrm{C}$ di Universitas Tadulako.

\section{Metode Penelitian}

Penelitian dilakukan pada bulan Desember 2020 berlokasi di Universitas Tadulako Jl. Soekarno Hatta, KM. 9, Tondo, Mantikulore, Kota Palu, Sulawesi Tengah.

Penelitian ini merupakan penelitian non eksperimental (observasional), dengan pendekatan metode cross sectional. Teknik sampling yang digunakan yaitu purposive sampling dimana pengambilan sampel berdasarkan pada kriteria inklusi dan eksklusi (Washburn et al., 2018). Responden pada penelitian ini adalah seluruh mahasiswa S1 angkatan 2017-2019 di Universitas Tadulako, yang terbagi menjadi mahasiswa kesehatan dan non kesehatan dengan total sebanyak 747 responden. Instrumen penelitian yang digunakan terdiri dari dua kuesioner yaitu kuesioner pengetahuan seputar tentang vitamin $\mathrm{C}$ dan kuesioner mengenai penggunaan vitamin $\mathrm{C}$. Kuesioner disebarkan secara online dalam bentuk Google Form yang telah diuji validitas serta reliabilitas. Setelah data terkumpul akan dilakukan analisis Chi-square menggunakan bantuan sistem program SPSS (statistical product and service solutions) yang digunakan untuk melihat hubungan antara tingkat pengetahuan dan penggunaan vitamin $\mathrm{C}$ di Universitas Tadulako.

\section{Hasil dan Pembahasan}

\section{a. Uji Validitas}

Uji validitas merupakan uji yang dilakukan untuk mengetahui bahwa kuesioner yang dibuat benar-benar dapat mengukur apa yang hendak diukur. Pada penelitian ini, untuk kuesioner pengetahuan tentang vitamin $\mathrm{C}$ dari 30 pernyataan, sebanyak 18 pernyataan dinyatakan valid serta layak untuk digunakan dan sebanyak 12 pernyataan dinyatakan tidak valid. Sedangkan untuk kuesioner penggunaan vitamin $\mathrm{C}$ dari 15 pernyataan, semua pernyataan valid dan layak untuk digunakan. Uji ini dilakukan dengan menggunakan aplikasi SPSS setelah kuesioner disebarkan dengan menggunakan Google Form pada 35 responden yang dibutuhkan, dengan ketentuan kuesioner dianggap layak apabila $r_{\text {hitung }}$ lebih besar dari $r_{\text {tabel }}$. Nilai $\mathrm{r}_{\text {tabel }}$ untuk 35 responden yaitu sebesar 0,334 . 
Tingkat Pengetahuan antara Mahasiswa Kesehatan dan Non Kesehatan terhadap Penggunaan Vitamin C di Universitas Tadulako Sulawesi Tengah

\section{b. Uji Reliabilitas}

Uji reliabilitas merupakan uji yang dilakukan untuk menunjukkan jika alat pengukur yang digunakan dapat dipercaya dan diandalkan, dimana kriteria uji reliabilitas variabel yang dikatakan baik jika memiliki nilai $r_{\text {alpha }}>r_{\text {tabel. }}$. Menurut (Suryadi et al., 2016), metode pengambilan keputusan untuk uji reliabilitas menggunakan batasan 0,6. Dari hasil yang didapatkan pada uji reliabilitas nilai Cronbach's Alpha pada kuesioner pengetahuan tentang vitamin $\mathrm{C}$ yaitu sebesar 0,724 kriteria reliabilitas tinggi dan pada kuesioner penggunaan vitamin $\mathrm{C}$ yaitu sebesar 0,761 kriteria reliabilitas tinggi yang berarti kedua kuesioner tersebut dikatakan reliable karena memiliki nilai Cronbach's alpha lebih besar dari 0,6.

\section{c. Deskripsi Responden Mahasiswa Universitas Tadulako}

Tabel 1

Data karakteristik responden

\begin{tabular}{|c|c|c|c|}
\hline Variabel & Kategori & $\begin{array}{c}\text { Jumlah } \\
\text { Responden } \\
\text { n }=747\end{array}$ & $\begin{array}{c}\text { Persenta } \\
\text { se }(\%)\end{array}$ \\
\hline \multirow{2}{*}{ Usia } & 17-20 tahun & 390 & 52,2 \\
\hline & 21-24 tahun & 357 & 47,8 \\
\hline \multirow{4}{*}{$\begin{array}{c}\text { Jenis } \\
\text { Kelamin }\end{array}$} & Total & 747 & 100 \\
\hline & Laki-Laki & 234 & 31,3 \\
\hline & $\overline{\text { Perempuan }}$ & 513 & 68,7 \\
\hline & Total & 747 & 100 \\
\hline \multirow{4}{*}{ Angkatan } & 2017 & 342 & 45,8 \\
\hline & 2018 & 237 & 31,7 \\
\hline & 2019 & 168 & 22,5 \\
\hline & Total & 747 & 100 \\
\hline \multirow{5}{*}{$\begin{array}{c}\text { Program } \\
\text { Studi } \\
\text { (Mahasiswa } \\
\text { Kesehatan) }\end{array}$} & Farmasi & 213 & 60,7 \\
\hline & Gizi & 35 & 10,0 \\
\hline & Kedokteran & 28 & 8,0 \\
\hline & $\begin{array}{l}\text { Kesehatan } \\
\text { Masyarakat }\end{array}$ & 75 & 21,3 \\
\hline & Total & 351 & 100 \\
\hline \multirow{10}{*}{$\begin{array}{c}\text { Fakultas } \\
\text { (Mahasiswa } \\
\text { Non } \\
\text { Kesehatan) }\end{array}$} & Ekonomi & 45 & 11,4 \\
\hline & Hukum & 38 & 9,6 \\
\hline & FISIP & 34 & 8,6 \\
\hline & FKIP & 76 & 19,2 \\
\hline & Kehutanan & 16 & 4,0 \\
\hline & FMIPA & 81 & 20,5 \\
\hline & Pertanian & 21 & 5,3 \\
\hline & $\overline{\text { Peternakan }}$ & 16 & 4,0 \\
\hline & Teknik & 69 & 17,4 \\
\hline & Total & 396 & 100 \\
\hline
\end{tabular}

Pada uraian ini akan dijelaskan karakteristik pada 747 responden berupa usia, jenis kelamin, angkatan, program studi dan fakultas. Pada tabel 1 dijelaskan bahwa berdasarkan kategori usia dominan responden yang mengisi kuesioner berada di rentang usia 17-20 tahun dengan jumlah 390 orang $(52,2 \%)$. Berdasarkan penelitian yang dilakukan oleh (Damayanti \& Achyani, 2017), bahwa usia mahasiswa yang sedang menempuh pendidikan untuk strata 1 (S1) umumnya berusia sekitar 1824 tahun. Berdasarkan kategori jenis kelamin, dominan responden yang mengisi kuesioner adalah responden yang berjenis kelamin perempuan dengan jumlah 513 orang $(68,7 \%)$. Menurut (Ivoryanto \& Illahi, 2017) hal ini dikarenakan perempuan lebih fokus dan lebih memberikan perhatian penuh pada topik yang dibicarakan jika dibandingkan lakilaki berdasarkan kategori angkatan, responden terbanyak berasal dari angkatan 2017 sebanyak 342 orang (45,8\%). Berdasarkan kategori program studi dari mahasiswa kesehatan, program studi dengan responden terbanyak adalah Farmasi sebanyak 213 orang $(60,7 \%)$. Berdasarkan kategori fakultas dari mahasiswa non kesehatan fakultas dengan responden terbanyak adalah FMIPA sebanyak 81 orang $(20,5 \%)$.

\section{d. Pengetahuan Mahasiswa Kesehatan} Dan Non Kesehatan Tentang Vitamin C

\section{Tabel 2}

Distribusi kategori pengetahuan mahasiswa kesehatan tentang Vitamin

\begin{tabular}{lcccc}
\multicolumn{5}{c}{$\mathbf{C}$} \\
\hline \multirow{2}{*}{ Kategori } & $\begin{array}{c}\text { Rata- } \\
\text { Rata } \\
\text { Skor }\end{array}$ & $\begin{array}{c}\text { Rata-Rata } \\
\text { Persentase } \\
(\boldsymbol{\%})\end{array}$ & $\begin{array}{c}\text { Jumlah } \\
\text { (orang) }\end{array}$ & $\begin{array}{c}\text { Persentase } \\
(\mathbf{\%})\end{array}$ \\
\hline Baik & 14,48 & 80,46 & 56 & 15,95 \\
\hline Cukup & $\mathbf{1 1 , 9 2}$ & $\mathbf{6 6 , 2 3}$ & $\mathbf{1 6 5}$ & $\mathbf{4 7 , 0 1}$ \\
\hline Kurang & 8,96 & 49,79 & 130 & 37,04 \\
\hline
\end{tabular}


Tabel 3

Distribusi kategori pengetahuan mahasiswa non kesehatan tentang

Vitamin C

\begin{tabular}{lcccc}
\hline Kategori & $\begin{array}{c}\text { Rata- } \\
\text { Rata } \\
\text { Skor }\end{array}$ & $\begin{array}{c}\text { Rata-Rata } \\
\text { Persentase } \\
(\boldsymbol{\%})\end{array}$ & $\begin{array}{c}\text { Jumlah } \\
\text { (orang) }\end{array}$ & $\begin{array}{c}\text { Persentase } \\
(\boldsymbol{\%})\end{array}$ \\
\hline Baik & 14,44 & 80,25 & 18 & 4,55 \\
\hline Cukup & 11,58 & 64,34 & 160 & 40,40 \\
\hline Kurang & $\mathbf{8 , 9 4}$ & $\mathbf{4 9 , 6 7}$ & $\mathbf{2 1 8}$ & $\mathbf{5 5 , 0 5}$ \\
\hline
\end{tabular}

Berdasarkan tabel 2 dan 3 hasil pengetahuan mahasiswa kesehatan dan non kesehatan tentang Vitamin $\mathrm{C}$ dengan masing-masing mahasiswa kesehatan sebanyak 351 orang dan mahasiswa non kesehatan sebanyak 396 orang. Menurut (Nursalam, 2011), pengukuran pengetahuan dapat diinterpretasikan menjadi 3 kategori yaitu kategori baik jika berkisar antara 76\%-100\%, kategori cukup jika berkisar antara 56\%-75\%, dan kategori kurang jika berkisar $<56 \%$ dari seluruh pernyataan. Dari hasil tersebut dapat disimpulkan bahwa pengetahuan dari mahasiswa kesehatan dominan masuk dalam kategori cukup sebanyak 165 orang $(47,01 \%)$ dengan rata-rata persentase skor adalah $66,23 \%$, sedangkan pengetahuan dari mahasiswa non kesehatan dominan masuk dalam kategori kurang sebanyak 218 orang $(55,05 \%)$ dengan rata-rata persentase skor adalah 49,67\%. Hal ini sesuai dengan penelitian yang dilakukan oleh (Rahmadhani et al., 2017), didapatkan hasil sebanyak 79,66\% pengetahuan mahasiswa masuk dalam kategori cukup yang dimana mahasiswa masih kurang memahami dan menyepelekan tentang vitamin $\mathrm{C}$ karena mereka hanya mengikuti trend penggunaan vitamin $\mathrm{C}$ semata. Dari hasil tersebut juga dapat disimpulkan secara umum bahwa tingkat pengetahuan mahasiswa kesehatan lebih besar dibandingkan pengetahuan mahasiswa non kesehatan. Ada beberapa faktor yang dapat mempengharuhi tingkat pengetahuan seseorang terhadap suatu hal, yaitu pendidikan, informasi, sosial, lingkungan, ekonomi, budaya, pengalaman, dan usia. Menurut (Widayati et al., 2012), pendidikan sangat berpengaruh terhadap pengetahuan seseorang. Informasi suatu hal dapat diperoleh seseorang melalui pendidikannya. Semakin banyaknya informasi yang diterima, semakin mudah dan cepat bagi seseorang untuk memperbarui pengetahuannya dan membentuk landasannya terhadap suatu hal. Sehingga perbedaan latar belakang pendidikan dapat berpengaruh terhadap pengetahuan seseorang.

\section{Tabel 4}

Distribusi frekuensi pengetahuan mahasiswa kesehatan tentang Vitamin C

\begin{tabular}{|c|c|c|c|}
\hline \multirow[t]{2}{*}{ Indikator } & \multicolumn{3}{|c|}{$\begin{array}{c}\text { Jumlah dan Persentase responden } \\
\text { Mahasiswa Kesehatan }\end{array}$} \\
\hline & Baik & Cukup & Kurang \\
\hline \multirow{2}{*}{ Definisi } & 197 & 0 & 154 \\
\hline & $(56,13 \%)$ & $(0,00 \%)$ & $(43,87 \%)$ \\
\hline \multirow{2}{*}{$\begin{array}{c}\text { Peran dan } \\
\text { Manfaat }\end{array}$} & 37 & 186 & 128 \\
\hline & $(10,54 \%)$ & $(52,99 \%)$ & $(36,47 \%)$ \\
\hline \multirow{2}{*}{ Sumber } & 86 & 159 & 106 \\
\hline & $(24,50 \%)$ & $(45,30 \%)$ & $(30,20 \%)$ \\
\hline \multirow{2}{*}{$\begin{array}{c}\text { Efek } \\
\text { Samping }\end{array}$} & 40 & 82 & 229 \\
\hline & $(11,40 \%)$ & $(23,36 \%)$ & $(65,24 \%)$ \\
\hline \multirow{2}{*}{ Lain-lain } & 246 & 72 & 33 \\
\hline & $(70,09 \%)$ & $(20,51 \%)$ & $(9,40 \%)$ \\
\hline
\end{tabular}

Tabel 5

Distribusi frekuensi pengetahuan mahasiswa non kesehatan tentang Vitamin C

\begin{tabular}{cccc}
\hline \multirow{2}{*}{ Indikator } & \multicolumn{3}{c}{ Jumlah dan Persentase responden } \\
& \multicolumn{3}{c}{ Mahasiswa Non Kesehatan } \\
\cline { 2 - 4 } & Baik & Cukup & Kurang \\
\hline \multirow{2}{*}{ Definisi } & $\mathbf{2 3 9}$ & 0 & 157 \\
\cline { 2 - 4 } & $\mathbf{( 6 0 , 3 5 \% )}$ & $(0,00 \%)$ & $(39,65 \%)$ \\
\hline Peran dan & 43 & $\mathbf{1 8 6}$ & 167 \\
\cline { 2 - 4 } Manfaat & $(10,86 \%)$ & $\mathbf{( 4 6 , 9 7 \% )}$ & $(42,17 \%)$ \\
\hline \multirow{2}{*}{ Sumber } & 64 & $\mathbf{1 8 3}$ & 149 \\
\cline { 2 - 4 } & $(16,16 \%)$ & $\mathbf{( 4 6 , 2 1 \% )}$ & $(37,63 \%)$ \\
\hline Efek & 17 & 60 & $\mathbf{3 1 9}$ \\
\cline { 2 - 4 } Samping & $(4,29 \%)$ & $(15,15 \%)$ & $\mathbf{( 8 0 , 5 6 \% )}$ \\
\hline \multirow{2}{*}{ Lain-lain } & $\mathbf{2 0 9}$ & 107 & 80 \\
\cline { 2 - 4 } & $\mathbf{( 5 2 , 7 8 \% )}$ & $(27,02 \%)$ & $(20,20 \%)$ \\
\hline
\end{tabular}

Berdasarkan tabel 4 dan 5 merupakan hasil responden berdasarkan 
Tingkat Pengetahuan antara Mahasiswa Kesehatan dan Non Kesehatan terhadap Penggunaan Vitamin C di Universitas Tadulako Sulawesi Tengah

indikator kuesioner pengetahuan mahasiswa/i kesehatan dan non kesehatan di Universitas Tadulako tentang vitamin C. Indikator definisi terdiri dari 1 pernyataan tentang definisi vitamin $\mathrm{C}$ yang dimana banyak mahasiswa yang paham tentang definisi dari vitamin $\mathrm{C}$ dilihat dari hasil jawaban mahasiswa kesehatan sebanyak $(56,13 \%)$ dan mahasiswa non kesehatan sebanyak $(60,35 \%)$ yang masuk dalam kategori baik hal ini dikarenakan definisi dari vitamin $\mathrm{C}$ merupakan pengetahuan yang umum bagi mahasiswa di Universitas Tadulako. Indikator peran atau manfaat yang teridiri dari 3 pernyataan tentang peran atau manfaat dari vitamin $\mathrm{C}$, belum sepenuhnya dipahami secara maksimal serta sering menyepelekan peran ataupun manfaat dari vitamin $\mathrm{C}$ itu sendiri, dari hasil jawaban untuk mahasiswa kesehatan sebesar $(52,99 \%)$ dan untuk mahasiswa non kesehatan sebesar $(46,97 \%)$ masuk dalam kategori cukup. Salah satu manfaat dari vitamin $\mathrm{C}$ yaitu mampu untuk memproduksi kolagen dan membantu meningkatkan proses penyerapan kalsium di dalam tubuh sehingga memiliki peran besar dalam pertumbuhan tulang (Hapzah \& Supriandi, 2018). Indikator sumber terdiri dari 3 pernyataan yang berisi tentang sumber vitamin $\mathrm{C}$ itu sendiri diperoleh, hasil jawaban responden untuk mahasiswa kesehatan sebanyak $(45,30 \%)$ dan untuk mahasiswa non kesehatan sebanyak $(46,21 \%)$ masuk dalam kategori cukup, hal ini dikarenakan masih banyak mahasiswa yang menyepelekan sumber vitamin C itu diperoleh. Menurut (Rahayu \& Mulyani, 2020), vitamin C dapat diperoleh dari buah-buahan segar diantaranya jeruk, jambu biji dan mangga serta dapat pula diperoleh dari sayursayuran seperti sawi, kol dan cabe. Indikator efek samping terdiri dari 6 pernyataan rata-rata jawaban benar untuk

mahasiswa kesehatan sebesar $(65,24 \%)$ dan mahasiswa non kesehatan sebesar $(80,56 \%)$ yang masuk dalam kategori kurang untuk keduanya, hal ini dikarenakan mahasiswa tidak banyak yang memperdulikan tentang efek samping dari vitamin C. Menurut (Nurmaini et al., 2020) jika vitamin $C$ dikonsumsi dengan dosis yang tepat maka dapat meminimalisir efek samping dari penggunaannya. Resiko efek samping dapat meningkat apabila dikonsumsi dalam jangka panjang dengan dosis lebih dari 2 gram sehari. Efek samping dari vitamin C kurang dirasakan oleh mahasiswa karena mereka mengkonsumsinya sesuai dengan dosis normalnya.

\section{e. Pengetahuan Mahasiswa Kesehatan Dan Non Kesehatan Tentang Penggunaan Vitamin C}

Tabel 6

Distribusi kategori pengetahuan

mahasiswa kesehatan tentang

Penggunaan Vitamin C

\begin{tabular}{lcccc}
\hline Kategori & $\begin{array}{c}\text { Rata- } \\
\text { Rata } \\
\text { Skor }\end{array}$ & $\begin{array}{c}\text { Rata-Rata } \\
\text { Persentase } \\
(\mathbf{\%})\end{array}$ & $\begin{array}{c}\text { Jumlah } \\
\text { (orang) }\end{array}$ & $\begin{array}{c}\text { Persentase } \\
(\boldsymbol{\%})\end{array}$ \\
\hline Baik & $\mathbf{1 3 , 0 6}$ & $\mathbf{8 7 , 0 7}$ & $\mathbf{2 1 6}$ & $\mathbf{6 1 , 5 4}$ \\
\hline Cukup & 10,44 & 69,60 & 109 & 31,05 \\
\hline Kurang & 7,23 & 48,21 & 26 & 7,41 \\
\hline
\end{tabular}

Tabel 7

Distribusi kategori pengetahuan

mahasiswa non kesehatan tentang Penggunaan Vitamin $\mathrm{C}$

\begin{tabular}{lcccc}
\hline Kategori & $\begin{array}{c}\text { Rata- } \\
\text { Rata } \\
\text { Skor }\end{array}$ & $\begin{array}{c}\text { Rata-Rata } \\
\text { Persentase } \\
(\boldsymbol{\%})\end{array}$ & $\begin{array}{c}\text { Jumlah } \\
\text { (orang) }\end{array}$ & $\begin{array}{c}\text { Persentase } \\
(\mathbf{\%})\end{array}$ \\
\hline Baik & 12,68 & 84,50 & 151 & 38,13 \\
\hline Cukup & $\mathbf{1 0 , 1 4}$ & $\mathbf{6 7 , 6 0}$ & $\mathbf{1 9 3}$ & $\mathbf{4 8 , 7 4}$ \\
\hline Kurang & 7,19 & 47,95 & 52 & 13,13 \\
\hline
\end{tabular}

Berdasarkan tabel 6 dan 7 hasil pengetahuan mahasiswa kesehatan dan non kesehatan tentang penggunaan Vitamin C dengan masing-masing mahasiswa kesehatan sebanyak 351 orang 
dan mahasiswa non kesehatan sebanyak 396 orang. Menurut (Nursalam, 2011), pengukuran pengetahuan dapat diinterpretasikan menjadi 3 kategori yaitu kategori baik jika berkisar antara 76\%100\%, kategori cukup jika berkisar antara $56 \%-75 \%$, dan kategori kurang jika berkisar $<56 \%$ dari seluruh pernyataan. Pada penelitian ini penggunaan vitamin $\mathrm{C}$ pada mahasiswa kesehatan dominan masuk dalam kategori baik yaitu sebanyak 216 orang $(61,54 \%)$ dengan rata-rata persentase skor adalah $87,07 \%$, sedangkan mahasiswa non kesehatan dominan masuk pada kategori cukup sebanyak 193 orang $(48,74 \%)$ dengan rata-data persentase skor adalah $67,60 \%$. Berdasarkan penelitian yang dilakukan oleh (Ramadhan, 2016) bahwa sebanyak $51,6 \%$ responden yang dalam hal ini mahasiswa masuk dalam kategori tingkat pengetahuan sedang atau cukup terkait penggunaan antioksidan (vitamin $\mathrm{C}$ dan vitamin E). Hal ini dikarenakan sebagian besar mahasiswa kurang mendapatkan informasi tentang antioksidan dimana informasi tersebut didapatkan melalui pendidikan seseorang baik formal maupun non formal yang dapat mempengaruhi perubahan dan peningkatan pengetahuan seseorang.

Tabel 8

Distribusi kategori pengetahuan mahasiswa kesehatan tentang penggunaan Vitamin $C$

\begin{tabular}{cccc}
\hline \multirow{2}{*}{ Indikator } & \multicolumn{3}{c}{$\begin{array}{c}\text { Jumlah dan Persentase responden } \\
\text { Mahasiswa Kesehatan }\end{array}$} \\
\cline { 2 - 4 } & Baik & Cukup & Kurang \\
\hline \multirow{2}{*}{ Penggunaan } & $\mathbf{2 1 6}$ & 109 & 26 \\
& $(\mathbf{6 1 , 5 4 \% )}$ & $(31,05 \%)$ & $(7,41 \%)$ \\
\hline
\end{tabular}

Tabel 9

\begin{tabular}{|c|c|c|c|}
\hline \multicolumn{4}{|c|}{$\begin{array}{c}\text { Distribusi kategori pengetahuan } \\
\text { mahasiswa non kesehatan tentang } \\
\text { penggunaan Vitamin C }\end{array}$} \\
\hline \multirow[t]{2}{*}{ Indikator } & \multicolumn{3}{|c|}{$\begin{array}{c}\text { Jumlah dan Persentase responden } \\
\text { Mahasiswa Non Kesehatan } \\
\end{array}$} \\
\hline & Baik & Cukup & Kurang \\
\hline Penggunaan & $\begin{array}{c}151 \\
(38,13 \%)\end{array}$ & $\begin{array}{c}193 \\
(48,74 \%)\end{array}$ & $\begin{array}{c}52 \\
(13,13 \%)\end{array}$ \\
\hline
\end{tabular}

Berdasarkan tabel 8 dan 9 indikator kuesioner penggunaan didapatkan hasil sebanyak 216 responden $(61,54 \%)$ dari jawaban mahasiswa kesehatan Universitas Tadulako tentang penggunaan vitamin $\mathrm{C}$ masuk dalam kategori baik. Sedangkan pada mahasiswa non kesehatan didapatkan hasil sebanyak 193 responden $(48,74 \%)$ masuk dalam kategori cukup. Berdasarkan penelitian yang telah dilakukan oleh (Koutsakos et al., 2021), didapatkan hasil mayoritas mahasiswa fakultas kedokteran Universitas Sumatera Utara memiliki pengetahuan yang baik mengenai penggunaan vitamin $\mathrm{C}$ secara oral, tetapi masih terdapat beberapa mahasiswa yang memiliki pengetahuan kurang. Kurangnya pengetahuan mengenai penggunaan vitamin $\mathrm{C}$ ini dapat berdampak negatif atau terjadi penyalahgunaan dosis. Jika kelebihan vitamin $\mathrm{C}$ maka efek samping yang dapat dirasakan yaitu dapat memicu peningkatan asam lambung, alergi dan iritasi pada kulit serta dapat mengganggu proses penyerapan vitamin B12. Sementara itu beberapa gejala yang dirasakan apabila tubuh kekurangan atau mengalami defisiensi vitamin $\mathrm{C}$ yaitu mudah merasa lelah, kulit menjadi kering, penyembuhan luka yang menjadi sulit, nyeri otot, kulit menjadi mudah memar serta terjadi peradangan pada gusi (Krisnanda et al., 2020).

\section{f. Hubungan Tingkat Pengetahuan \\ Mahasiswa Kesehatan dan Non Kesehatan Terhadap Penggunaan Vitamin C di Universitas Tadulako Tabel 10 Hasil Uji Chi-Square

\begin{tabular}{|c|c|c|c|}
\hline & Value & Df & $\begin{array}{c}\text { Asymp. Sig } \\
\text { (2-sided) }\end{array}$ \\
\hline $\begin{array}{l}\text { Pearson Chi- } \\
\text { Square }\end{array}$ & $64,752^{a}$ & 4 & 0.000 \\
\hline Nof Valid Cases & 747 & & \\
\hline
\end{tabular}

Berdasarkan tabel 10 hasil uji statistik Chi-Square pada pengujian 
Tingkat Pengetahuan antara Mahasiswa Kesehatan dan Non Kesehatan terhadap Penggunaan Vitamin C di Universitas Tadulako Sulawesi Tengah

hubungan tingkat pengetahuan mahasiswa kesehatan dan non kesehatan terhadap penggunaan vitamin $\mathrm{C}$ didapatkan nilai Chi-Square $_{\text {hitung }}$ (Nilai hasil uji chi-square menggunakan SPSS 21) sebesar 64,752 dengan nilai signifikansi sebesar 0.000 , maka jika dilihat dari nilai signifikansi, nilai $0.000<0.05$ sehingga disimpulkan bahwa $\mathrm{H}_{\mathrm{O}}$ ditolak dan $\mathrm{H}_{1}$ diterima. Sehingga terdapat hubungan antara tingkat pengetahuan mahasiswa kesehatan dan non kesehatan dengan penggunaan vitamin C di Universitas Tadulako, hal ini sesuai dengan penelitian yang dilakukan oleh (Wibowo, 2015) yang mendapatkan hasil signifikansi sebesar $0,000 \quad(<0,05)$ sehingga menunjukan bahwa adanya hubungan antara pengetahuan terhadap perilaku penggunaan suplemen kesehatan yang salah satunya adalah vitamin $C$, ini dikarenakan responden akan mencari informasi mengenai suplemen yang akan dikonsumsi atau digunakan. Hasil dari penelitian ini menujukan bahwa adanya hubungan antara pengetahuan dan penggunaan maka dapat disimpulkan semakin baik tingkat pengetahuan mahasiswa kesehatan dan non kesehatan tentang vitamin $\mathrm{C}$ maka semakin baik pula penggunaan vitamin $\mathrm{C}$.

\section{Kesimpulan}

Pertama pengetahuan pada mahasiswa kesehatan di Universitas Tadulako tentang vitamin $\mathrm{C}$ lebih banyak di kategori cukup sebanyak 165 orang $(47,01 \%)$ dibandingkan dengan mahasiswa non kesehatan yang lebih banyak di kategori kurang sebanyak 218 orang $(59,01 \%)$.

Kedua penggunaan pada mahasiswa kesehatan di Universitas Tadulako tentang penggunaan vitamin $\mathrm{C}$ lebih banyak dikategori baik sebanyak 216 orang $(61,54 \%)$ dibandingkan dengan mahasiswa non kesehatan yang lebih banyak di kategori cukup sebanyak 193 orang $(48,74 \%)$.
Ketiga Dari hasil uji chi-square didapatkan bahwa terdapat hubungan signifikan antara tingkat pengetahuan dengan penggunaan vitamin $\mathrm{C}$ pada mahasiswa/i kesehatan dan non kesehatan, Universitas Tadulako.

\section{BIBLIOGRAFI}

Damayanti, S., \& Achyani, F. (2017). Analisis Pengaruh Investasi, Likuiditas, Profitabilitas, Pertumbuhan Perusahaan Dan Ukuran Perusahaan Terhadap Kebijakan Deviden Payout Ratio (Studi Empiris Pada Perusahaan Manufaktur Yang Terdaftar Di Bej). Riset Akuntansi Dan Keuangan Indonesia, 5(1), 51-62. Google Scholar

Hapzah, H., \& Supriandi, S. (2018). Asupan Kalsium Dan Vitamin C Dengan Tinggi Badan Siswa Sd Negeri Inpres BeruBeru Kecamatan Kalukku Kabupaten Mamuju. Jurnal Kesehatan Manarang, 2(2), 95-98. Google Scholar

Ivoryanto, E., \& Illahi, R. K. (2017). Hubungan Tingkat Pendidikan Formal Masyarakat Terhadap Pengetahuan Dalam Penggunaan Antibiotika Oral Di Apotek Kecamatan Klojen. Pharmaceutical Journal of Indonesia, 2(2), 31-36. Google Scholar

Koutsakos, M., Rowntree, L. C., Hensen, L., Chua, B. Y., Van De Sandt, C. E., Habel, J. R., Zhang, W., Jia, X., Kedzierski, L., \& Ashhurst, T. M. (2021). Integrated Immune Dynamics Define Correlates Of Covid-19 Severity And Antibody Responses. Cell Reports Medicine, 2(3), 100208. Google Scholar

Krisnanda, T., Tham, G. Y., Paternostro, M., \& Paterek, T. (2020). Observable Quantum Entanglement Due To Gravity. Npj Quantum Information, 6(1), 1-6. Google Scholar

Ngginak, J., Rupidara, A., \& Daud, Y. (2019). Analisis Kandungan Vitamin C 
Siti Mutmaina Ayu Lestari, Amelia Rumi dan Khusnul Diana

Dari Ekstrak Buah Ara (Ficus Carica L) Dan Markisa Hutan (Passiflora Foetida L). Jurnal Sains Dan Edukasi Sains, 2(2), 54-59. Google Scholar

Notoatmodjo, S. (2012). Metodologi Penelitian Kesehatan. Google Scholar

Nurmaini, S., Darmawahyuni, A., Sakti Mukti, A. N., Rachmatullah, M. N., Firdaus, F., \& Tutuko, B. (2020). Deep Learning-Based Stacked Denoising And Autoencoder For Ecg Heartbeat Classification. Electronics, 9(1), 135. Google Scholar

Nursalam. (2011). Proses Dan Dokumentasi Keperawatan. Jakarta: Salemba Medik. Google Scholar

Polak, C. L., Malonda, N. S. H., \& Amisi, M. D. (2021). Gambaran Kecukupan Vitamin Larut Air Pada Mahasiswa Semester Vi Di Fakultas Kesehatan Masyarakat Universitas Sam Ratulangi Manado Selama Masa Pandemi Covid19. Kesmas, 10(2). Google Scholar

Rahayu, C. D., \& Mulyani, S. (2020). Pengambilan Keputusan Klinis Perawat. Jurnal Ilmiah Kesehatan, 10(1), 1-11. Google Scholar

Rahmadhani, R., Zaharan, N. L., Mohamed, Z., Moy, F. M., \& Jalaludin, M. Y. (2017). The Associations Between Vdr Bsmi Polymorphisms And Risk Of Vitamin D Deficiency, Obesity And Insulin Resistance In Adolescents Residing In A Tropical Country. Plos One, 12(6), E0178695. Google Scholar

Ramadhan, A. F. (2016). Persepsi Mahasiswa Dalam Menggunakan E-Money. Jurnal Dinamika Ekonomi \& Bisnis, 13(2). Google Scholar

Rhama, B., Timang, J. H., Palangka, J. R., \& Raya, K. P. (2020). The Meta-Analysis Of Ecotourism In National Parks. African Journal Of Hospitality, Tourism And Leisure, 9(1), 1-17. Google Scholar
Ri, K. (2016). Kementerian Kesehatan Republik Indonesia. 2018. Pedoman Umum Gizi Seimbang. Jakarta (Id): Direktorat Jenderal Bina Kesehatan Masyarakat. Google Scholar

Siti, N., Agustina, A., \& Nurhaini, R. (2016). Penetapan Kadar Vitamin C Pada Jerami Nangka (Artocarpus Heterpophyllus L.). Jurnal Farmasi Sains Dan Praktis, 2(1), 1-5. Google Scholar

Sukmawati, D., Sondana, G. A., Fikriyyah, N. N., Afifah, Z. N., Firhandini, A., Khumaiya, U., Komsiatun, D. A., Asmara, Y. T., Supiyani, A., \& Puspitaningrum, R. (2021). CellulaseProducing Yeast Isolated From Fermented Cocoa Beans As Biocontrol For Pathogenic Mold Chocolate Fruit Collected From Sentul, Jawa Barat, Indonesia. Journal of Physics: Conference Series, 1869(1), 12043. Google Scholar

Suryadi, Y., Priyatno, T. P., Samudra, I., Susilowati, D. N., Lawati, N., \& Kustaman, E. (2016). Pemurnian Parsial Dan Karakterisasi Kitinase Asal Jamur Entomopatogen Beauveria Bassiana Isolat Bb200109. Google Scholar

Trisnawati, Y., Purwanti, S., \& Retnowati, M. (2016). Studi Deskriptif Pengetahuan Dan Sikap Ibu Hamil Tentang Gizi 1000 Hari Pertama Kehidupan Di Puskesmas Sokaraja Kabupaten Banyumas. Jurnal Kebidanan, 8(02). Google Scholar

Washburn, A. N., Hanson, B. E., Motyl, M., Skitka, L. J., Yantis, C., Wong, K. M., Sun, J., Prims, J. P., Mueller, A. B., \& Melton, Z. J. (2018). Why Do Some Psychology Researchers Resist Adopting Proposed Reforms To Research Practices? A Description Of Researchers' Rationales. Advances In Methods And Practices In Psychological Science, 1(2), 166-173. Google Scholar

Wibowo, K. M. (2015). Dkk.(2015). Sistem Informasi Geografis (Sig) Menentukan 
Tingkat Pengetahuan antara Mahasiswa Kesehatan dan Non Kesehatan terhadap Penggunaan Vitamin C di Universitas Tadulako Sulawesi Tengah

Lokasi Pertambangan Batu Bara Di Provinsi Bengkulu Berbasis Website. Jurnal Media Infotama, 11(1). Google Scholar

Widayati, A., Suryawati, S., De Crespigny, C., \& Hiller, J. E. (2012). Knowledge And Beliefs About Antibiotics Among People In Yogyakarta City Indonesia: A Cross Sectional Population-Based Survey. Antimicrobial Resistance And
Infection Control, 1(1), 1-7. Google Scholar

Wijayanti, S., \& Sungkono, J. (2017). Pengembangan Perangkat Pembelajaran Mengacu Model Creative Problem Solving Berbasis Somatic, Auditory, Visualization, Intellectually. Al-Jabar: Jurnal Pendidikan Matematika, 8(2), 101-110. Google Scholar

\section{Copyright holder:}

Siti Mutmaina Ayu Lestari, Amelia Rumi dan Khusnul Diana (2021)

First publication right:

Jurnal Health Sains

This article is licensed under: 